\begin{tabular}{|c|c|c|}
\hline Beitr. Ent. & Keltern & ISSN 0005-805X \\
\hline $\mathbf{6 0}(2010) 1$ & S. $13-32$ & 31.07 .2010 \\
\hline
\end{tabular}

\title{
Phylogenetic relationships of the bumblebees Bombus moderatus, B. albocinctus, B. burjaeticus, B. florilegus and $B$. cryptarum based on mitochondrial DNA markers: a complex of closely related taxa with circumpolar distribution
}

\section{(Hymenoptera: Apidae: Bombus)}

With 6 figures and 4 tables

Andreas Bertsch, Martin Hrabé de Angelis and Gerhard K. H. Przemeck

\section{Zusammenfassung}

Königinnen von Bombus moderatus aus Alaska/USA und Alberta/Canada und von B. burjaeticus and B. patagiatus aus dem Russischen Transbaikal wurden an verschiedenen Orten im Frühjahr gefangen, um künstliche Kolonien zu züchten. Zusätzlich wurden Männchen von B. florilegus in Hokkaido/Japan gesammelt. Teilsequenzen (Länge 1005 bp) mitochondrialer Cytochrome Oxidase Untereinheit I (COI) wurde sequenziert. Zum Vergleich wurden auch Museumsproben von B. albocinctus und B. burjaeticus sequenziert. Die Divergenz der Sequenzen innerhalb der Taxa beträgt 1 bis 2 Basen-Substitutionen und die Tamura-Nei Genetische Distanz 0.001-0.002. Die Divergenz der Sequenzen zwischen B. moderatus, B. albocinctus und $B$. burjaeticus beträgt nur 1-5 Basen-Substitutionen und die Tamura-Nei Genetische Distanz 0.001-0.005, während die Divergenz der Sequenzen zwischen B. lucorum, B. magnus, B. patagiatus und B. cryptarum 22-44 Basen Substitutionen beträgt und die Tamura-Nei Genetische Distanz 0.027-0.042. Zusätzlich zu den Clustern für B. lucorum, B. magnus und B. patagiatus zeigt die Topologie des Phylogramms (MrBayes Maximum Likelihood Tree) ein umfangreiches Cluster, in dem B. albocinctus, B. burjaeticus, $B$. moderatus und $B$. florilegus vereinigt sind. Da die COI Sequenzen keine Lücken aufweisen, können die einzelnen Nukleotide wie homologe Positionen verwendet werden. Jedes Taxon besitzt 8-20 eigene Substitutionen, die als diagnostische Positionen zur Charakterisierung des Taxons verwendet werden können. Die Analyse der diagnostischen Positionen der Taxa bestätigt die Topologie des Maximum Likelihood Phylogramms. Um die Lücke zwischen den östlichsten bekannten Vorkommen von B. cryptarum im Kaukasus und im Elburz und den Vorkommen von B. burjaeticus/B.albocinctus im Russischen Transbaikal und in Russisch Fernost zu überbrücken, wurden 12 weitere Museumsproben aus Zentralasiatischen Gebirgen und dem Himalaja sequenziert. Durch Analyse der diagnostischen Positionen der teilweise 100 Jahre alten DNA kann gezeigt werden, dass keine dieser Proben zu B. lucorum gehören kann, alle bilden ein Cluster mit den Taxa des cryptarum Komplexes.

\section{Summary}

Spring queens of Bombus moderatus from Alaska/USA and Alberta/Canada, and of B. burjaeticus and $B$. patagiatus from the Russian Transbaikal region were collected at different localities. In addition, males of $B$. florilegus were collected from Hokkaido/Japan. Partial sequences (length $1005 \mathrm{bp}$ ) of mitochondrial cytochrome oxidase subunit I (COI) were sequenced from specimens from each locality and species. For comparison, museum specimens of B. albocinctus and B. burjaeticus were also sequenced. The intraspecific sequence divergence was only 1-2 base substitutions and about $0.001-0.002$ in Tamura-Nei genetic dis- 
tance. The interspecific sequence divergence between $B$. moderatus, B. albocinctus and B. burjaeticus was only $1-5$ base substitutions and about $0.001-0.005$ in Tamura-Nei genetic distance, whereas the sequence divergence between $B$. lucorum, B. magnus, B. patagiatus and B. cryptarum was about 24-44 base substitutions and approximately $0.027-0.042$ in Tamura-Nei genetic distance. The MrBayes maximum likelihood tree generated a tree topology with three separate clusters for B. lucorum, B. magnus and B. patagiatus, and one large cluster which united $B$. albocinctus, B. burjaeticus, B. moderatus and B. florilegus. Because there are no gaps in the alignments of COI sequences, single nucleotide sites were used as positional homologies. Each taxon was characterised by about 8-20 substitutions which were unique ("private") and could be used as diagnostic characters to define and identify these taxa. An analysis of the number of diagnostic characters confirmed the clustering of the maximum likelihood tree. To bridge the gap of about $5000 \mathrm{~km}$ between the most eastern known localities for B. cryptarum in the Caucasus and Elburz Mountains and B. burjaeticus/ B. albocinctus in the Russian Transbaikal region and the Russian Far East, 12 more museum specimens from the Central Asiatic Mountains and the Himalayas were sequenced. By analysing the diagnostic positions in the sequences of this almost 100-year-old museum DNA, it was shown that none were connected with B. lucorum: they all clustered within the cryptarum-complex taxa.

\section{Introduction}

The taxon Bombus cryptarum (FABRICIUs 1775), initially described from the type locality Hafniae (Copenhagen), re-described as B. lucorum var. pseudocryptarum SкоRikov (1913) from Poland and Russia, and as B. lucorum var. lucocryptarum BALL (1914) from Belgium, was established as a species by RASMONT $(1981,1983)$. It took another 25 years until this species, with a European distribution, was accepted as separate from $B$. lucorum by morphology, male labial gland secretions and DNA sequences (BerTsch 1997; BerTsch et al. 2004, 2005; Bertsch 2009). Bombus cryptarum is distributed throughout Europe. It is more or less abundant in parts of Great Britain, the Netherlands, Benelux, parts of France, in Northern and Middle Germany, Scandinavia, Finland, Poland and Lithuania. The distribution in Belarus and Russia still has to be investigated, but museum specimens and fieldwork in St. Petersburg and Moscow show that the species is also common there. Museum specimens from Tscheljabinsk/Russia make its distribution throughout Northern Russia very probable, at least till the Urals. The available data also show that B. cryptarum is less abundant in the Southern parts of these countries. The abundance and distribution in the Alps of France, Switzerland and Austria still has to be fully investigated, otherwise the alpine distribution continues through the Balkan Mountains and the highlands of North Eastern Anatolia into the Caucasus and the Talesh and Elburz Mountains in Iran.

By investigating isoenzyme markers, Scholl et al. (1990) were able to show that the North American B. moderatus Cresson, 1863, was closely related to the European B. cryptarum, a view confirmed by DNA sequences (BERTsCH et al. 2010). These sequences also showed that the Russian Far Eastern taxon B. albocintus Sмiтh, 1854, and the North American B. moderatus belong to the same taxon, and that this Pan-Pacific $B$. albocinctus is not the Far Eastern representative of B. lucorum as discussed by Vogt (1911), Bischoff (1930), Krüger (1951), Tkalcu (1974), Lelej \& Kupianskaya (2000), Davydova (2001), and Davydova \& Pesenko (2002) but is closely related, if not conspecific, to the European B. cryptarum. Between the specimens B. cryptarum from the Urals, the Caucasus and the Talesh and Elburz Mountains, and the Russian Far Eastern specimens of B. albocinctus/burjaeticus, a gap of about $5000 \mathrm{~km}$ has to be closed.

To investigate the relationships between the European B. cryptarum and the Russian Far Eastern $B$. albocinctus, we obtained partial sequences from the mitochondrial cytochrome oxidase subunit 
I (COI) gene of Bombus sensu stricto taxa from the Russian Transbaikal region, the Russian Far East and museum specimens from the Central Asiatic Mountains (Alai, Kirghizian and Dzungarian Alatau) and the Himalayas, and addressed the following issues: (1) whether the Russian Far East Genbank sequences designated as B. cryptarum were identical with the taxon $B$. albocinctus; (2) whether there were close relationships between $B$. albocinctus and the Siberian taxon $B$. patagiatus Nylander, 1948, the Transbaikal region taxon B. burjaeticus KRÜGER, 1951 and the taxon B.florilegus Panfilov, 1956 (= B. terrestris var. japonica FrIESE 1909) from the Kuril Islands and Hokkaido; and (3) whether it was possible to close the gap between the Transbaikal region taxa and the $B$. cryptarum specimens from Anatolia, the Caucasus and Elburz Mountains using museum specimens from the Central Asiatic Mountains.

\section{Materials and Methods}

\section{Bumblebee samples}

Table 1 shows the bumblebee samples used for DNA sequencing with their identification codes and the localities of their origins with geographical coordinates. Figure 1 shows a pacific-centred world map with the distributions of B. cryptarum, B. burjaeticus, B. albocintus, and $B$. moderatus. Figure 6 shows the distribution of $B$. florilegus between Hokkaido/Japan and the North Kuril Islands. From the museum collections, 18 specimens were also sequenced and Table 2 gives their identification codes, their original designations and the localities of their origins with geographical coordinates. The localities for these museum specimens with their identification numbers are also included in Figure 1. In order to check the identity

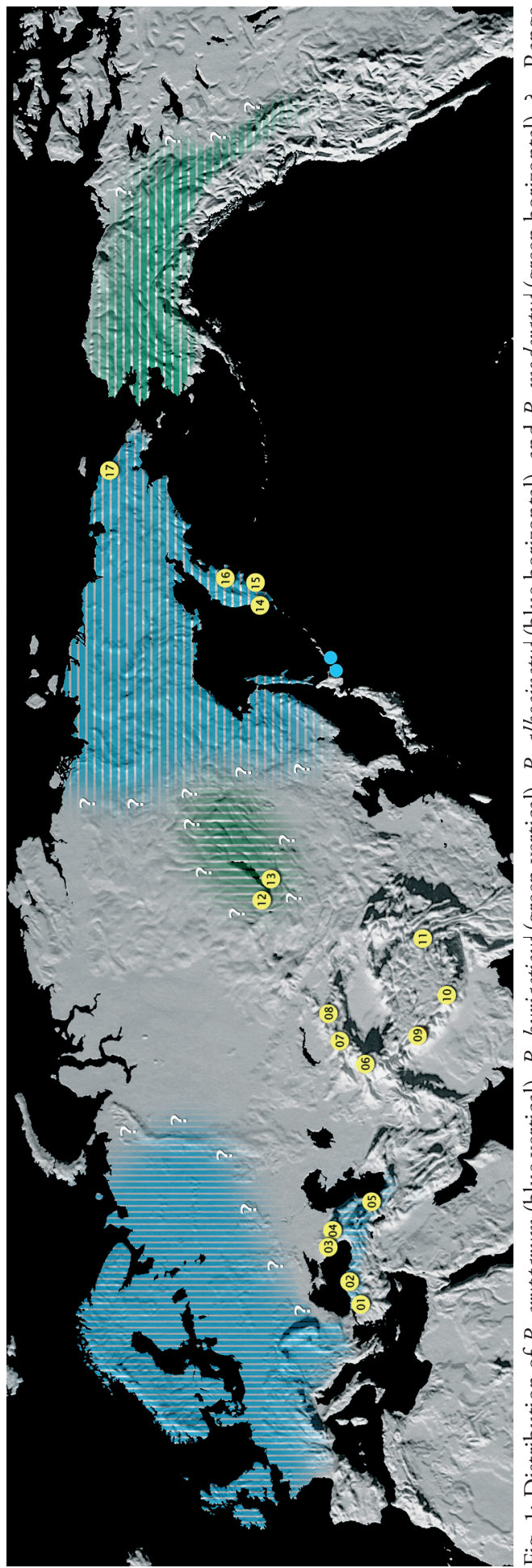


Bertsch, A.; Hrabé de Angelis, M. \& Przemeck, G. K.H.: Phylogenetic relationships

\begin{tabular}{|c|c|c|c|c|c|c|c|}
\hline Code & Locality & Country & Region & Latitude & Longitude & Altitude & \\
\hline Mag-01 & Glenmore Forest & UK & Scotland & $57^{\circ} 09.83^{\prime} \mathrm{N}$ & $03^{\circ} 41.31^{\prime} \mathrm{W}$ & $334 \mathrm{~m}$ & $\mathrm{Q}, \mathrm{aC} \rightarrow \mathrm{M}$ \\
\hline Mag-02 & Menz & Germany & Brandenburg & $53^{\circ} 06.84^{\prime} \mathrm{N}$ & $12^{\circ} 68.54^{\prime} \mathrm{E}$ & $85 \mathrm{~m}$ & AY530015 \\
\hline Mag-03 & Marcinkonys & Lithuania & Alytus County & $54^{\circ} 21.04^{\prime} \mathrm{N}$ & $24^{\circ} 25.46^{\prime} \mathrm{E}$ & $145 \mathrm{~m}$ & $\mathrm{Q}, \mathrm{aC} \rightarrow \mathrm{M}$ \\
\hline Cry-01 & Loch Swannay & UK & Orkney Mainland & $59^{\circ} 08.53^{\prime} \mathrm{N}$ & $03^{\circ} 12.24^{\prime} \mathrm{E}$ & $51 \mathrm{~m}$ & $\mathrm{Q}, \mathrm{aC} \rightarrow \mathrm{M}$ \\
\hline Cry-02 & Hillside & UK & Burray/Orkney Isl. & $58^{\circ} 51.29^{\prime} \mathrm{N}$ & $02^{\circ} 56.29^{\prime} \mathrm{E}$ & $50 \mathrm{~m}$ & $\mathrm{Q}, \mathrm{aC} \rightarrow \mathrm{M}$ \\
\hline Cry-03 & Porlock Hill & UK & Devon/England & $51^{\circ} 09.48^{\prime} \mathrm{N}$ & $03^{\circ} 34.64^{\prime} \mathrm{W}$ & $417 \mathrm{~m}$ & $\mathrm{Q}, \mathrm{aC} \rightarrow \mathrm{M}$ \\
\hline Cry-04 & Roth & Germany & Franken/Bayern & $59^{\circ} 59.87^{\prime} \mathrm{N}$ & $09^{\circ} 17.03^{\prime} \mathrm{E}$ & $231 \mathrm{~m}$ & Q \\
\hline Cry-05 & Menz & Germany & Brandenburg & $54^{\circ} 21.04^{\prime} \mathrm{N}$ & $24^{\circ} 25.46^{\prime} \mathrm{E}$ & $145 \mathrm{~m}$ & $\mathrm{Q}, \mathrm{aC} \rightarrow \mathrm{M}$ \\
\hline Cry-06 & Menz & Germany & Brandenburg & $54^{\circ} 21.04^{\prime} \mathrm{N}$ & $24^{\circ} 25.46^{\prime} \mathrm{E}$ & $145 \mathrm{~m}$ & AY530012 \\
\hline Cry-07 & Marcinkonys & Lithuania & Alytus County & $54^{\circ} 21.04^{\prime} \mathrm{N}$ & $24^{\circ} 25.46^{\prime} \mathrm{E}$ & $145 \mathrm{~m}$ & $\mathrm{Q}, \mathrm{aC} \rightarrow \mathrm{M}$ \\
\hline Cry-08 & Vent & Austria & Ötztal/Tirol & $46^{\circ} 52.07^{\prime} \mathrm{N}$ & $10^{\circ} 54.44^{\prime} \mathrm{E}$ & $2320 \mathrm{~m}$ & M \\
\hline Cry-09 & Nassfeld & Austria & Kärnten & $46^{\circ} 34.49^{\prime} \mathrm{N}$ & $13^{\circ} 06.26^{\prime} \mathrm{E}$ & $1415 \mathrm{~m}$ & Q \\
\hline Cry-10 & Sölk Pass & Austria & Steiermark & $46^{\circ} 52.07^{\prime} \mathrm{N}$ & $10^{\circ} 54.44^{\prime} \mathrm{E}$ & $1780 \mathrm{~m}$ & AY181124 \\
\hline CRY-11 & Julier Pass & $\begin{array}{l}\text { Switzer- } \\
\text { land }\end{array}$ & Albula/Graubünden & $46^{\circ} 28.16^{\prime} \mathrm{N}$ & $09^{\circ} 43.31^{\prime} \mathrm{E}$ & $2280 \mathrm{~m}$ & AY181124 \\
\hline CRY-12 & Five Ness/Crail & UK & Five/Scotland & $56^{\circ} 16.41^{\prime} \mathrm{N}$ & $02^{\circ} 35.15^{\prime} \mathrm{W}$ & $10 \mathrm{~m}$ & $\mathrm{Q}, \mathrm{aC} \rightarrow \mathrm{M}$ \\
\hline Cry-13 & Duncansby Head & UK & Caithness/Scotland & $58^{\circ} 38.34^{\prime} \mathrm{N}$ & $03^{\circ} 01.46^{\prime} \mathrm{W}$ & $50 \mathrm{~m}$ & $\mathrm{Q}, \mathrm{aC} \rightarrow \mathrm{M}$ \\
\hline Cry-14 & Duncansby Head & UK & Caithness/Scotland & $58^{\circ} 38.34^{\prime} \mathrm{N}$ & $03^{\circ} 01.46^{\prime} \mathrm{W}$ & $50 \mathrm{~m}$ & AY530011 \\
\hline FLO-01 & Iturup/Etoforu & Russia & Kurilsky Distr. & $45^{\circ} 05.45^{\prime} \mathrm{N}$ & $147^{\circ} 52.43^{\prime} \mathrm{E}$ & & AF279487 \\
\hline FLO-02 & Nemuro & Japon & Hokkaido & $42^{\circ} 21.40^{\prime} \mathrm{N}$ & $145^{\circ} 44.50^{\prime} \mathrm{E}$ & & AF279486 \\
\hline Flo-03 & Tomoshiri & Japon & Hokkaido & $43^{\circ} 19.35^{\circ} \mathrm{N}$ & $145^{\circ} 39.57^{\prime} \mathrm{E}$ & $25 \mathrm{~m}$ & $\mathrm{M}$ \\
\hline FLO-04 & Tomoshiri & Japon & Hokkaido & $43^{\circ} 19.35^{\circ} \mathrm{N}$ & $145^{\circ} 39.57^{\prime} \mathrm{E}$ & $25 \mathrm{~m}$ & $\mathrm{M}$ \\
\hline ALB-01 & Kamchatka & Russia & Kamchatka Krai & & & & AF279482 \\
\hline Alb-02 & Paramushir & Russia & Sakhalin Obl. & $50^{\circ} 39.48^{\circ} \mathrm{N}$ & $156^{\circ} 05.45^{\prime} \mathrm{E}$ & & AF279483 \\
\hline ALB-04 & Shumshu & Russia & Sakhalin Obl. & $50^{\circ} 44.46^{\prime} \mathrm{N}$ & $156^{\circ} 22.41^{\prime} \mathrm{E}$ & & AF279484 \\
\hline ALB-04 & Magadan & Russia & Magadan Obl. & $59^{\circ} 38.07^{\prime} \mathrm{N}$ & $150^{\circ} 49.05^{\prime} \mathrm{E}$ & & AF279485 \\
\hline Mod-01 & Denali & USA & Alaska & $62^{\circ} 39,91^{\prime} \mathrm{N}$ & $150^{\circ} 20.42^{\prime} \mathrm{W}$ & $195 \mathrm{~m}$ & $\mathrm{Q}, \mathrm{aC} \rightarrow \mathrm{M}$ \\
\hline Mod-02 & Broad Pass & USA & Alaska & $63^{\circ} 19.31^{\prime} \mathrm{N}$ & $149^{\circ} 09.21^{\prime} \mathrm{W}$ & $725 \mathrm{~m}$ & $\mathrm{Q}, \mathrm{aC} \rightarrow \mathrm{M}$ \\
\hline Mod-03 & Paxon & USA & Alaska & $63^{\circ} 00.94^{\prime} \mathrm{N}$ & $145^{\circ} 31.05^{\prime} \mathrm{W}$ & $950 \mathrm{~m}$ & $\mathrm{Q}, \mathrm{aC} \rightarrow \mathrm{M}$ \\
\hline Mod-04 & Isabel Pass & USA & Alaska & $63^{\circ} 11.77^{\prime} \mathrm{N}$ & $145^{\circ} 33.64^{\prime} \mathrm{W}$ & $1095 \mathrm{~m}$ & $\mathrm{Q}, \mathrm{aC} \rightarrow \mathrm{M}$ \\
\hline Mod-05 & Isabel Pass & USA & Alaska & $63^{\circ} 11.77^{\prime} \mathrm{N}$ & $145^{\circ} 33.64^{\prime} \mathrm{W}$ & $1095 \mathrm{~m}$ & Q \\
\hline Mod-06 & Ya-Ha-Tinda & Canada & Alberta & $51^{\circ} 44.57^{\prime} \mathrm{N}$ & $115^{\circ} 32.52^{\prime} \mathrm{W}$ & $1615 \mathrm{~m}$ & M \\
\hline Mod-07 & Sheep River & Canada & Alberta & $50^{\circ} 39.11^{\prime} \mathrm{N}$ & $114^{\circ} 21.85^{\prime} \mathrm{W}$ & $1315 \mathrm{~m}$ & M \\
\hline Bur-01 & Listvyanka & Russia & Irkutsk Obl. & $51^{\circ} 52.25^{\prime} \mathrm{N}$ & $104^{\circ} 50.15^{\prime} \mathrm{E}$ & $620 \mathrm{~m}$ & $\mathrm{Q}, \mathrm{aC} \rightarrow \mathrm{M}$ \\
\hline Bur-02 & Yablonowo & Russia & Chitinsky Distr. & $51^{\circ} 50.58^{\prime} \mathrm{N}$ & $112^{\circ} 45.20^{\prime} \mathrm{E}$ & $965 \mathrm{~m}$ & $\mathrm{Q}, \mathrm{aC} \rightarrow \mathrm{M}$ \\
\hline Bur-03 & Ozero Tasey & Russia & Chitinsky Distr. & $52^{\circ} 14.29^{\prime} \mathrm{N}$ & $112^{\circ} 57.05^{\prime} \mathrm{E}$ & $1005 \mathrm{~m}$ & Q \\
\hline Bur-04 & Chita & Russia & Zabaikalsky Krai & $52^{\circ} 00.54^{\prime} \mathrm{N}$ & $113^{\circ} 28.35^{\prime} \mathrm{E}$ & $750 \mathrm{~m}$ & $\mathrm{Q}, \mathrm{aC} \rightarrow \mathrm{M}$ \\
\hline Bur-05 & $\begin{array}{l}\text { Chita, Kadala } \\
\text { Airport }\end{array}$ & Russia & Zabaikalsky Krai & $52^{\circ} 01.15^{\prime} \mathrm{N}$ & $113^{\circ} 18.22^{\prime} \mathrm{E}$ & $675 \mathrm{~m}$ & Q \\
\hline Bur-06 & Kadachta & Russia & Karymski Distr. & $51^{\circ} 37.22^{\prime} \mathrm{N}$ & $114^{\circ} 14.56^{\prime} \mathrm{E}$ & $650 \mathrm{~m}$ & $\mathrm{Q}, \mathrm{aC} \rightarrow \mathrm{M}$ \\
\hline Bur-07 & Kadachta & Russia & Karymski Distr. & $51^{\circ} 37.22^{\prime} \mathrm{N}$ & $114^{\circ} 14.56^{\prime} \mathrm{E}$ & $650 \mathrm{~m}$ & Q \\
\hline Luc-01 & Chita & Russia & Chitinskaja Obl. & $52^{\circ} 00.86^{\prime} \mathrm{N}$ & $113^{\circ} 28.56^{\prime} \mathrm{E}$ & $730 \mathrm{~m}$ & $\mathrm{Q}, \mathrm{aC} \rightarrow \mathrm{M}$ \\
\hline Luc-02 & Yakutsk & Russia & Sakha Republic & $62^{\circ} 01.82^{\prime} \mathrm{N}$ & $129^{\circ} 44.09^{\prime} \mathrm{E}$ & $115 \mathrm{~m}$ & AF279497 \\
\hline Luc-03 & Brøstrud & Norway & Buskerud & $60^{\circ} 18.22^{\prime} \mathrm{N}$ & $08^{\circ} 34.19^{\prime} \mathrm{E}$ & $920 \mathrm{~m}$ & AY181120 \\
\hline Pat-01 & Yakutsk & Russia & Sakha Republic & $62^{\circ} 01.82^{\prime} \mathrm{N}$ & $129^{\circ} 44.09^{\prime} \mathrm{E}$ & $115 \mathrm{~m}$ & AF279499 \\
\hline Pat-02 & Primorsk & Russia & Primorsky Krai & & & & AF279498 \\
\hline РАT-03 & Listvyanka & Russia & Irkutsk Obl. & $51^{\circ} 52.25^{\prime} \mathrm{N}$ & $104^{\circ} 50.15^{\prime} \mathrm{E}$ & $620 \mathrm{~m}$ & $\mathrm{Q}, \mathrm{aC} \rightarrow \mathrm{M}$ \\
\hline Pat-04 & Chita & Russia & Zabaikalsky Krai & $52^{\circ} 00.54^{\prime} \mathrm{N}$ & $113^{\circ} 28.35^{\prime} \mathrm{E}$ & $750 \mathrm{~m}$ & $\mathrm{Q}, \mathrm{aC} \rightarrow \mathrm{M}$ \\
\hline
\end{tabular}


Tab. 1: List of 40 Bombus samples $\left(\mathrm{MAG}_{\mathrm{A}}=\right.$ magnus, $\mathrm{CRY}=$ cryptarum, $\mathrm{FLO}=$ florilegus, $\mathrm{AlB}=$ albocinctus, $\mathrm{MOD}=$ moderatus, $\mathrm{BUR}=$ burjaeticus, $\mathrm{PAT}=$ patagiatus, and $\mathrm{LUC}=$ lucorum $)$ used in the present analysis with identification codes, and collection locality information. $\mathrm{Q}=$ queen, $\mathrm{aC} \rightarrow \mathrm{M}=$ artificial colonies with production of males.

of the specimens Bur-01-Bur-07 from the Transbaikal region, tentatively designated as B. burjaeticus with the material from Krüger, two paratype specimens of $B$. burjaeticus from Krügers material were sequenced (M-13-1, M-13-2), and as the specimens of $B$. albocinctus from the Russian Far East (Alb-01-Alb-04) were deposited in GenBank by Ito and Tanaka as B. cryptarum, three specimens from the type locality Kamchatka for B. albocinctus (M-14-M-16) were sequenced for comparison. Voucher specimens have been deposited at the Senckenberg Deutsches Entomologisches Institut, Müncheberg, Germany.

\section{Polymerase chain reaction (PCR) and DNA sequencing of mitochondrial COI}

Total DNA was extracted from legs using the QIAamp ${ }^{\oplus}$ DNA Mini Kit (Qiagen, Hilden, Germany) according to the manufacturer's specifications for tissue, and eluted in $150 \mu \mathrm{l}$ of highly purified water (Ampuwa ${ }^{\oplus}$, Fresenius Kabi, Bad Homburg, Germany). For sequence analysis, overlapping fragments (in all 1027 bp) of mitochondrial COI were amplified using primers specifically designed for Bombus. BO-1-fwd (5' TAGGATCACCAGATATAGC 3') and BO-K-rev (5' GAGCTCAAACAATAAATCC 3') resulted in the amplification of a 609 bp fragment, whereas BO-5-fwd (5' AATGAAAGAGGTAAAAAAGAAAC 3') and BO-A-rev (5' ATGTTGAGGGAAAAATGTTAT 3') resulted in the amplification of a $510 \mathrm{bp}$ fragment. Polymerase Chain Reaction amplifications were performed as described (BERTSCH et al. 2010). A sample of $10 \mu \mathrm{l}$ from each reaction was checked on a $1 \%$ agarose gel. Polymerase Chain Reaction products were purified using the AMPure ${ }^{\oplus}$ PCR Purification Kit (Agencourt, Beverly, MA, USA). Both strands were sequenced for all specimens. Sequencing reactions were performed using $\mathrm{ABI}^{\oplus}$ BigDye Terminator version 3.1 chemistry (Applied Biosystems, Foster City, CA, USA) according to manufacturer's instructions and they were then analysed on an ABI 3100 sequencer (Applied Biosystems). Sequences were aligned using ClustalX. No gaps or poorly aligned regions occurred in the alignment, but missing characters were trimmed from the ends of the alignment to produce an equal sequence length of $1005 \mathrm{bp}$ for all individuals (encoding 335 amino acids). Individual alignments were aligned against the complete COI gene sequence of Bombus ignitus between positions 262 and 1267 (GenBank DQ870926; CHA et al. 2007).

\section{Degraded DNA from museum specimens}

The 40-100 year old DNA from the museum specimens was more or less degraded. The integration of these sequences into MrBayes maximum likelihood simulations did not give useful results; depending on the grade of degradation, the specimens clustered in unpredictable ways. Therefore, the original ABI traces of these sequences had to be carefully inspected for degraded positions; whenever double peaks were detected the IUPAC Code for mixed bases (wobbles) was inserted. Where necessary, the Polymerase Chain Reaction was repeated with slightly adjusted amplification conditions, and by this procedure it was possible to get reliable sequences for the control specimens (M13-1, M13-2 and M14-M16), which were suitable for use in MrBayes simulations. About $97 \%$ (863 out of 891 ) of the positions in the sequences from the fresh material were invariant, therefore, for MrBayes simulations with the rest of the museum specimens, the variability of the degraded DNA was reduced by deleting all the invariant triplets (of the fresh, not the degraded DNA) and only the triplets with parsimony informative positions were included in the analysis. 
Tab. 2: List of Bombus samples from Museum specimens (ZMA = Zoölogical Museum Amsterdam, Zsm $=$ Zoologische StaAtsammlungen München, Zmas $=$ Zoological Museum Russian Academy of Science St. Petersburg, Sem = Senckenberg Museum Frankfurt/M) used in the present analysis.

\begin{tabular}{|c|c|c|c|c|c|c|}
\hline Code & & Locality & Country & Latitude & Longitude & \\
\hline M-01 & $\begin{array}{l}\text { lucorum terrestriformis VoGT, } \\
\text { 1911:56 }\end{array}$ & Bursa/Bakazak & Turkey & $40^{\circ} 06.09^{\prime} \mathrm{N}$ & $29^{\circ} 12.56^{\prime} \mathrm{E}$ & ZSM \\
\hline M-02 & $\begin{array}{l}\text { cryptarum armeniensis RASMONT, } \\
1984: 154\end{array}$ & Ilgaz Pass & Turkey & $41^{\circ} 03.94^{\prime} \mathrm{N}$ & $33^{\circ} 45.00^{\prime} \mathrm{E}$ & ZSM \\
\hline M-03 & lucorum (LinNAEUs, 1761) & Mt. Bombak & Russia & $43^{\circ} 57.00^{\prime} \mathrm{N}$ & $40^{\circ} 60.00^{\prime} \mathrm{E}$ & ZMAS \\
\hline M-04 & lucorum & River Bezymyanka & Russia & ?? & ?? & ZMAS \\
\hline M-05 & $\begin{array}{l}\text { cryptarum iranicus KRÜGER, } \\
1951: 196\end{array}$ & Col de Rovra & Iran & $38^{\circ} 40.00^{\prime} \mathrm{N}$ & $48^{\circ} 21.00^{\prime} \mathrm{E}$ & ZSM \\
\hline M-06 & $\begin{array}{l}\text { lucorum alaiensis REINIG, 1930: } \\
107\end{array}$ & Kisil Beles & Kyrgyzstan & $40^{\circ} 16.98^{\prime} \mathrm{N}$ & $73^{\circ} 16.19^{\prime} \mathrm{E}$ & ZMA \\
\hline M-07 & $\begin{array}{l}\text { magnus turkestanicus KRÜGER, } \\
\text { 1954:274 }\end{array}$ & Naryn & Kyrgyzstan & $41^{\circ} 26.32^{\prime} \mathrm{N}$ & $76^{\circ} 01.34^{\prime} \mathrm{E}$ & ZMA \\
\hline M-08 & $\begin{array}{l}\text { magnus borochorensis KRÜGER, } \\
1954: 273\end{array}$ & Burchan Canyon & Kazachstan & $44^{\circ} 21.05^{\prime} \mathrm{N}$ & $80^{\circ} 04.80^{\prime} \mathrm{E}$ & ZMA \\
\hline M-09 & $\begin{array}{l}\text { lucorum jacobsoni SKORIKOV, } \\
\text { 1912:610 }\end{array}$ & Sind Valley Baltal & India & $34^{\circ} 15.26^{\prime} \mathrm{N}$ & $75^{\circ} 25.00^{\prime} \mathrm{E}$ & ZMA \\
\hline M-10 & reinigi TKalCU, 1974:322 & Phoksumo Lake & Nepal & $29^{\circ} 10.43^{\prime} \mathrm{N}$ & $82^{\circ} 56.46^{\prime} \mathrm{E}$ & $\mathrm{ZMF}$ \\
\hline M-11 & $\begin{array}{l}\text { lucorum terrestricoloratus KRÜGER, } \\
1951: 196\end{array}$ & ?? & China & ?? & ?? & ZMA \\
\hline M-12 & $\begin{array}{l}\text { lucorum mongolicus VoGT, 1909: } \\
42\end{array}$ & Irkutsk & Russia & $52^{\circ} 17.21^{\prime} \mathrm{N}$ & $104^{\circ} 18.45^{\prime} \mathrm{E}$ & ZMAS \\
\hline M-13-1 & burjaeticus KRÜGER, 1951:148 & Kulskoje & Russia & $52^{\circ} 05.81^{\prime} \mathrm{N}$ & $109^{\circ} 43.24^{\prime} \mathrm{E}$ & ZMA \\
\hline M-13-2 & burjaeticus & Nertschinsk & Russia & $51^{\circ} 59.20^{\prime} \mathrm{N}$ & $116^{\circ} 35.12^{\prime} \mathrm{E}$ & ZMA \\
\hline M-14 & $\begin{array}{l}\text { lucorum albocinctus SмITH, 1854: } \\
397\end{array}$ & Petropavlowsk & Russia & $53^{\circ} 01.20^{\prime} \mathrm{N}$ & $158^{\circ} 39.42^{\prime} \mathrm{E}$ & ZMAS \\
\hline M-15 & lucorum albocinctus & Kljutschi & Russia & $56^{\circ} 10.05^{\prime} \mathrm{N}$ & $160^{\circ} 51.21^{\prime} \mathrm{E}$ & ZMAS \\
\hline M-16 & lucorum albocinctus & Mouth river Opala & Russia & $51^{\circ} 40.87^{\prime} \mathrm{N}$ & $156^{\circ} 31.62^{\prime} \mathrm{E}$ & ZMAS \\
\hline M-17 & lucorum albocinctus & Cape Schmidt & Russia & $68^{\circ} 53.50^{\prime} \mathrm{N}$ & $179^{\circ} 25.00^{\prime} \mathrm{E}$ & ZMAS \\
\hline
\end{tabular}

\section{Analysis of sequence divergence of mitochondrial COI}

The absolute numbers of substitutions were counted based on a pair-wise comparison of the sequences. The analysis of sequence diversity was performed using the maximum composite likelihood method of Mega 4.0 (TAmura et al. 2007; Kumar et al. 2008). Because the distribution of nucleotides in the COI of Hymenoptera is known to be heterogeneous, with a strong $\mathrm{A}+\mathrm{T}$ bias, we selected the Tamura-Nei model of base substitution (TAmura \& Nei 1993) which corrects this bias in its assumption of sequence evolution. The nucleotide frequencies and the parameters necessary for this model were estimated from the sequence data and Tamura-Nei genetic distances were calculated. The best maximum likelihood model was selected using the JModelTest (Posada 2008). The tree topology was inferred by a maximum likelihood tree based on the general time-reversible model (GTR plus gamma), calculated by Bayesian analysis using MrBayes (Huelsenbeck \& Ronquist 2001). Tree topology was also calculated as a Minimum Evolution tree (ME) with bootstrap sampling using MEga 4.0 (TAMUra et al. 2007). Geneious Pro 4.5 (Biomatters Ltd.) was used to analyse the alignment and detect diagnostic positions and the GreenButton plugin (InterGrid) was used to do the time consuming MrBayes calculations on a supercomputer cluster. The nucleotide changes along the branches 
of cladograms were examined with MacClade 4.08 (Maddison \& Maddison 2002). The COI sequence data of B. soroeensis (GenBank AY181159; Pedersen 2002) were used as the outgroup.

\section{Results}

\section{Nucleotide frequencies and substitution parameters}

The aligned data matrix of 36 sequences (B. moderatus, B. albocinctus, B. florilegus and B. burjaeticus) of 891 bp length (encoding 297 amino acids) included 863 (97\%) invariants and 28 variable sites. Of these 28 variable positions, 3 were parsimony uninformative (noise) and 25 parsimony informative (signal). However, differences in this pattern were evident in codon positions, where only 1 informative site was in first position and all of the other 24 informative variant sites were in third position. None of these sites was a replacement position; the singleton replacement position 1007 in the GenBank sequence AF279485 was most probably an amplification error or a miscoding lesion. Table 3 shows the pattern of nucleotide substitutions estimated from the data with the maximum composite likelihood model (MEGA). The nucleotide frequencies were $33.1(\mathrm{~A}), 42.1(\mathrm{~T}), 12.3(\mathrm{C})$ and $12.5(\mathrm{G})$, which proves the known strong $\mathrm{A}+\mathrm{T}$ bias typical for sequences of Hymenoptera.

\section{COI sequence divergence between and within species}

Table 4 presents the matrix of genetic distances estimated by the Tamura-Nei model and as p-distances within and between the five taxa investigated: B. cryptarum, B. florilegus, B. albocinctus, $B$. moderatus and $B$. burjaeticus. For comparison and discussion the sequences of the European species, B. lucorum (Luc-01-Luc-03), B. magnus (MAG-01-MAG-03) and the Asiatic species B. patagiatus (РАT-01-PAT-03) were included in the analysis. The intraspecific genetic variability was low for all taxa (1-2 nucleotides, Tamura-Nei distance 0.001-0.002). By contrast, the interspecific genetic variability between $B$. lucorum, B. magnus, B. patagiatus and B. cryptarum was approximately one order of magnitude larger (25-44 nucleotides, Tamura-Nei distance 0.027-0.042).

The Tamura-Nei genetic distance between B. burjaeticus and B. albocinctus is only 0.002 , both taxa are conspecific, and $B$. moderatus, with a Tamura-Nei genetic distance to $B$. albocinctus/ $B$. burjaeticus of 0.004 , also belongs to the same taxon; the larger genetic distance manifested the geographic separation of this taxon by the Bering Strait. Bombus florilegus, with a Tamura-Nei genetic distance between 0.010 and 0.014 to $B$. moderatus/ $B$. albocinctus/ $B$. burjaeticus was clearly distinct but not a separate species. All these taxa had a Tamura-Nei genetic distance between 0.012 and 0.018 to B. cryptarum, again with the largest genetic distance for the geographically separated B. moderatus, therefore it seemed to be useful to treat all these taxa as members of a closely related complex of taxa, the cryptarum-complex. Bombus patagiatus was well separated from this cryptarum-complex by a Tamura-Nei genetic distance of 0.031 to 0.040 and $B$. magnus by a Tamura-Nei genetic distance of 0.030 to 0.037 , comparable with $B$. lucorum, which was separated by a Tamura-Nei genetic distance of 0.036 to 0.040 . These Tamura-Nei genetic distances are larger by one order of magnitude and revealed that all three taxa are separate species.

Tab. 3: Maximum Composite Likelihood Estimate of the Pattern of Nucleotide Substitution. The transition/transversion rate ratios are $\mathrm{k}_{1}=5.25$ (purines) and $\mathrm{k}_{2}=8.24$ (pyramidines), the overall transition/transversion bias is $\mathrm{R}=1.834$.

\begin{tabular}{|c|c|c|c|c|}
\hline & A & T & C & G \\
\hline A & - & 4.74 & 1.39 & 7.37 \\
\hline T & 3.73 & - & 11.42 & 1.4 \\
\hline C & 3.73 & 39.08 & - & 1.4 \\
\hline G & 19.6 & 4.74 & 1.39 & - \\
\hline
\end{tabular}




\section{Tree building by maximum likelihood models}

The maximum likelihood tree (Fig. 2) generated using the Bayesian Markov Chain Monte Carlo (MCMC) analysis with 1005 bp full-length sequences was based on the general time-reversible model of base substitution (GTR plus gamma). For comparison, GenBank data of the European taxa $B$. lucorum, B. cryptarum and B. magnus were included. This tree confirmed the results from the analysis of genetic distances: $B$. magnus and $B$. patagiatus are distinctly separated species, $B$. cryptarum, B. florilegus and the cluster $\gamma_{3}$ of $B$. albocinctus/B. burjaeticus/B. moderatus form a cluster $\gamma$ of closely related taxa with the geographically separated taxon $B$. moderatus as the most evolved end unit. All clusters had a high posterior probability and were distinctly separate from B. lucorum.

Tab. 4: Mean genetic distance within and between taxa. Diagonal and Lower left: TAMURA-Nei model, rates among sites gamma distributed. Upper right: p-distance.

\begin{tabular}{|l|c|c|c|c|c|c|c|c|}
\hline & Cry & Flo & Alb & Mod & Bur & Luc & Pat & MAG \\
\hline cryptarum & $\mathbf{0 . 0 0 1}$ & 0.012 & 0.014 & 0.018 & 0.015 & 0.037 & 0.029 & 0.029 \\
\hline florilegus & 0.012 & $\mathbf{0 . 0 0 1}$ & 0.010 & 0.014 & 0.011 & 0.034 & 0.029 & 0.025 \\
\hline albocinctus & 0.014 & 0.010 & $\mathbf{0 . 0 0 1}$ & 0.005 & 0.002 & 0.035 & 0.037 & 0.036 \\
\hline moderatus & 0.018 & 0.014 & 0.005 & $\mathbf{0 . 0 0 1}$ & 0.004 & 0.037 & 0.038 & 0.030 \\
\hline burjaeticus & 0.016 & 0.011 & 0.002 & 0.004 & $\mathbf{0 . 0 0 1}$ & 0.036 & 0.035 & 0.049 \\
\hline lucorum & 0.040 & 0.036 & 0.038 & 0.039 & 0.039 & $\mathbf{0 . 0 0 2}$ & 0.044 & 0.033 \\
\hline patagiatus & 0.031 & 0.031 & 0.036 & 0.042 & 0.041 & 0.038 & $\mathbf{0 . 0 0 1}$ & 0.036 \\
\hline magnus & 0.031 & 0.027 & 0.030 & 0.031 & 0.031 & 0.031 & 0.035 & $\mathbf{0 . 0 0 2}$ \\
\hline
\end{tabular}

\section{Tree building by diagnostic characters}

Because there are no gaps in the alignments of COI sequences, single nucleotide sites can be used as positional homologies (Hillis 1994). The alignment file (Fig. 3) showed that each taxon was characterised by substitutions which were unique ("private") and could be used as diagnostic characters to define and identify this taxon (Funk et al. 2001; Bertsch 2009). In MacClade, all of the changes at the nodes and the diagnostic characters at the last branch of the terminal units can be investigated in detail, and a tree with the classical tools for morphological characters can be built (Fig. 4). The conclusions drawn from the genetic distance data and the clustering of the maximum likelihood tree were fully confirmed by analysis of the diagnostic characters. The taxa B. albocinctus, B. burjaeticus and B. moderatus shared four positions, and B. moderatus, as a geographically separated taxon, had two diagnostic positions of its own; the analysis of the diagnostic positions confirmed that these taxa are conspecific. Bombus florilegus is closely related and characterised by two diagnostic positions, which is typical for isolated island populations. The combined B. albocinctus/ B. burjaeticus/B. moderatus taxon and B. florilegus shared five positions and a cluster with $B$. cryptarum, which was separated by six diagnostic positions. The taxa $B$. patagiatus, $B$. magus and $B$. lucorum had 16, 12 and 17 unambiguous diagnostic characters, respectively, and are separate species.

\section{Museum sequences $B$. albocinctus and B. burjaeticus}

The unpublished sequences from Magadan, Kamchatka and the Northern Kuril Islands, Shumshu and Paramushir, submitted to GenBank in 2000 by Ito \& Tanaka, were identified by morphological characteristics as specimens of $B$. cryptarum by Masao Ito. As so far there are no known specimens of typical $B$. cryptarum from these areas, it seemed necessary to prove the identity of these GenBank specimens with typical $B$. albocinctus. Therefore four typical specimens (collare, scutellum and second tergite white-coloured) of B. albocinctus from Kamchatka 


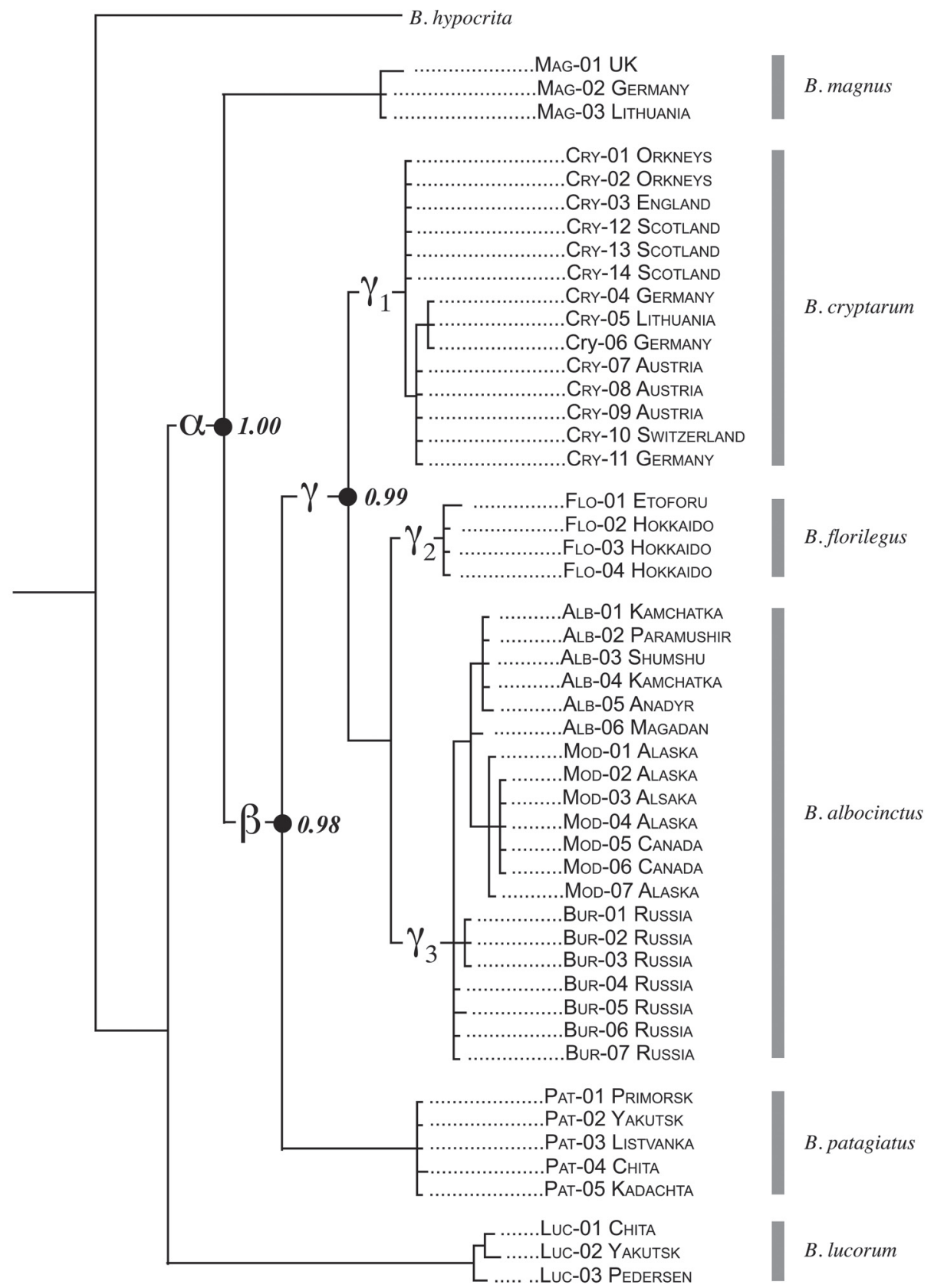

Fig. 2: Tree topology calculated as Maximum-Likelihood tree using Bayesian MCMC analysis with the general time reversal model of base substitutions with gamma distribution.

(M-14, M-15, M-16) and Chuchotka (M-17) from the collection of the Zoological Museum of the Academy of Sciences St. Petersburg (ZMAS) were sequenced. Two queens from the type series Kulskoje (M-13-1 \& M-13-2) of B. burjaeticus, from the Vogt collection of the Zoölogical 
Museum Amsterdam (ZMA), corresponding in morphology with Krüger's original description (yellow of bands greenish, upper part of episternum yellow) were sequenced to check their identity with queens collected during fieldwork during June 1994 in Transbaikal region.

The 40 to 100-year-old museum specimens had degraded DNA but the genetic connections were established by comparing the diagnostic positions (Fig. 5). As the Tamura-Nei genetic distance between $B$. albocinctus and B. burjaeticus was only 0.004 and both taxa are conspecific, the results for the museum specimens of both taxa are identical: they do not belong to $B$. lucorum as none of the 17 diagnostic positions of $B$. lucorum could be found. The sequences for the museum specimen B. burjaeticus (M-13-1 and M-13-2) and B. albocinctus (M-14 to M-17) shared the positions $328(\mathrm{~T} \rightarrow \mathrm{C}), 330(\mathrm{~A} \rightarrow \mathrm{T}), 751(\mathrm{~T} \rightarrow \mathrm{C})$ and $846(\mathrm{~T} \rightarrow \mathrm{G})$ with B. cryptarum and they differed from $B$. cryptarum by positions $531(\mathrm{~T} \rightarrow \mathrm{C}), 855(\mathrm{~T} \rightarrow \mathrm{G}), 818(\mathrm{C} \rightarrow \mathrm{T})$, and $1128(\mathrm{~T} \rightarrow \mathrm{C})$, positions characteristic for the Asiatic taxa of this complex.

\section{Degraded DNA of museum specimens}

As the alignment of the fresh material showed that $97 \%$ of the positions were invariable, we removed all invariable triplets from the alignment of the museum specimens and generated a maximum likelihood tree (Fig. 5) with the variable triplets using the Bayesian MCMC analysis with the general time-reversible model of base substitution (GTR plus gamma). For comparison, sequences of fresh material of B. cryptarum, B. albocinctus, B. burjaeticus and B. florilegus together with sequences of $B$. lucorum, $B$. magnus and $B$. patagiatus were included, as outgroup $B$. ignitus was used (GenBank DQ870926; CHA et al. 2007). This procedure implied the assumption that the museum specimens belong to one of the taxa investigated in this report.

The control specimens M-13-1 and M-13-2 of the type series B. burjaeticus and the control specimens M-14 to M-17 of $B$. albocinctus joined the cluster $\gamma_{3}$ with the fresh material of B. moderatus / B. albocinctus / B. burjaeticus, which proved that deletion of the invariable sites does not change the overall result. Depending on quality and length (sequences M-02 \& M-05 were too short to be included) of the degraded DNA, the specimens M-01, M-03, M-04 from Turkey, the Caucasus and Iran, areas from where B. cryptarum has been identified, joined the B. cryptarum cluster $\gamma_{1}$ or the cryptarum-complex cluster $\gamma$. All of the remaining specimens from the Central Asiatic mountains and the Himalayas whether identified as subspecies of B. lucorum (M-06, M09, M-12), as subspecies of B. magnus (M-07 and M-08) or as separate species B. reinigi (M-10) also joined the cluster $\gamma$ with the specimens of the cryptarum-complex taxa. The posterior probabilities were high; therefore, the conclusion that these specimens are not connected to B. lucorum but rather to $B$. cryptarum respectively to the cryptarum-complex taxa is reasonable.

\section{Discussion}

\section{Bombus patagiatus as a separate species}

This species was first described by NyLANDER (1848) and afterwards was neglected for a long time until it was established as a good species by TKaLCU (1967). The most obvious characteristic is the typical combination of yellow-white colouration (collare, scutellum, tergite), which is not a very useful feature in bumblebee taxonomy of critical taxa. TKALCU (1967) described morphological characteristics for this taxon (form of labrum, punctuation of vertex and ocellar field, ocellar distance, proportions of flagellum segments) and the differences between these characters compared to those of $B$. lucorum, but nearly all of these characteristics were so similar that terms such as 'a little bit more' and 'a little bit larger' ore 'sometimes a bit larger' were the best that could be said 

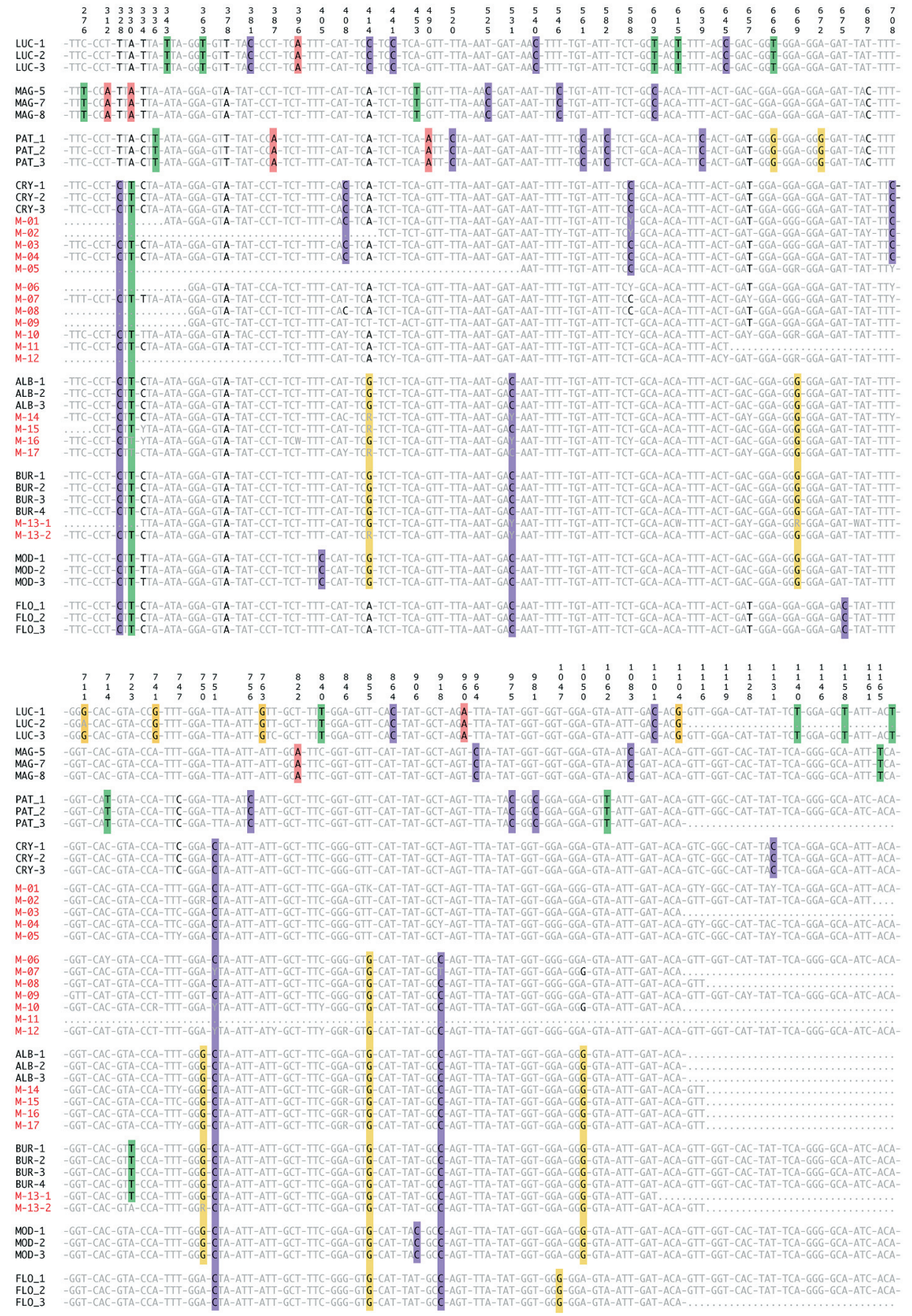

Fig. 3: Alignment of all parsimonious informative triplets (with uninformative sites deleted -), and with a pointer for position number (numbered for total COI) and codon position. Diagnostic (= private) positions marked with colour green $=$ Thymine, violet $=$ Cytosine, red $=$ Adenine and yellow $=$ Guanine . 


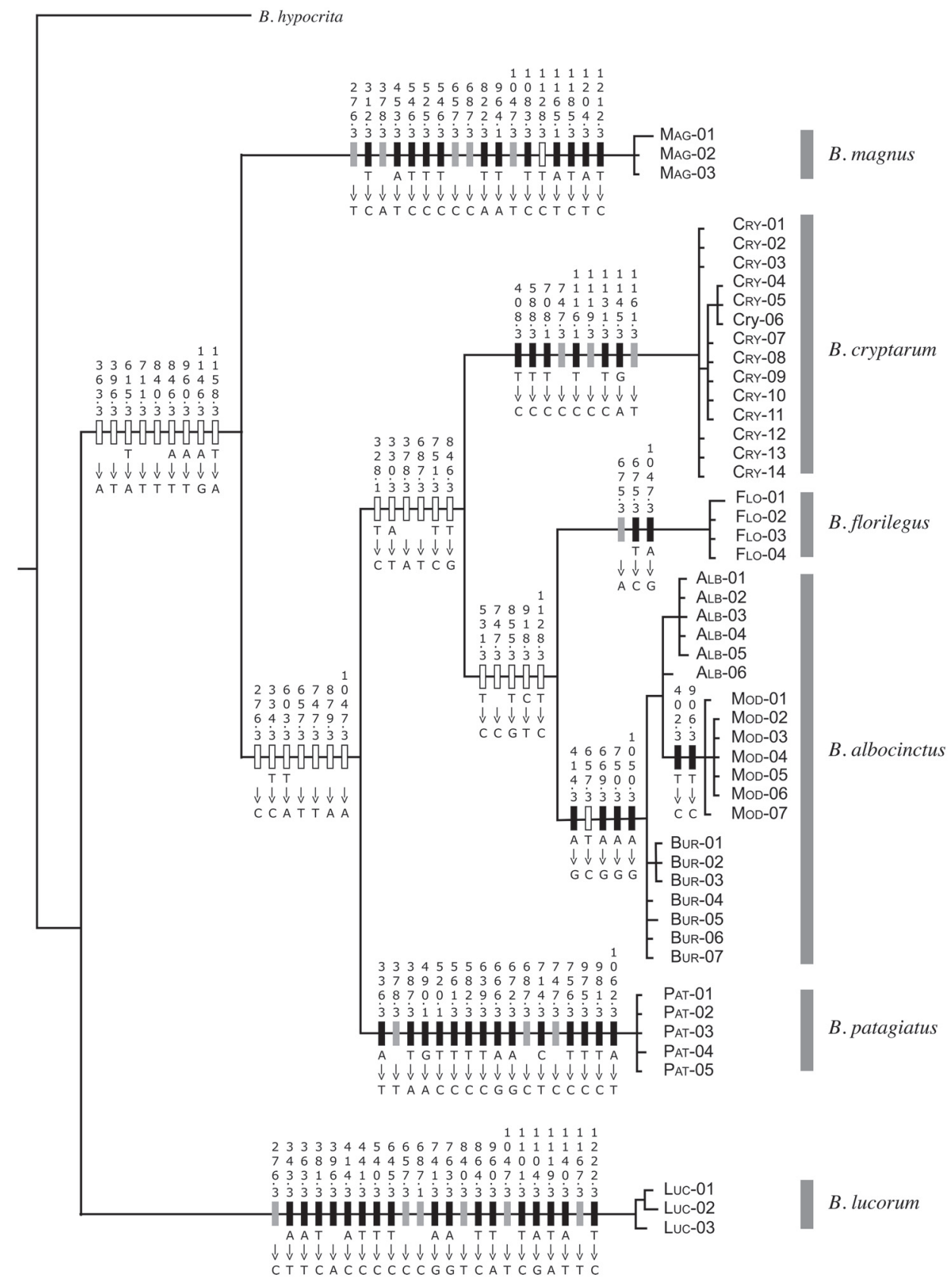

Fig. 4: Observed diagnostic character changes with position numbers mapped onto the MaximumLikelihood tree. Black box $=$ unambiguous diagnostic character change, grey box $=$ ambiguous diagnostic character change, and white box $=$ character change. 
[original in French]. RASMONT (1984:141) refers to these characters as morphologically very similar to B. cryptarum and comes to the conclusion that 'the two species for the moment cannot be distinguished by their morphology alone' [original in French]. The male labial gland secretions (BERTSCH et al. unpublished results) and the DNA sequences confirmed a close relationship but they also showed also that $B$. patagiatus, with 14 unambiguous diagnostic positions, is a separate species. The sympatric distribution of $B$. albocinctus and B. patagiatus in parts of Russia (Yakutia, Primorsk and Sakhalin), where both taxa are abundant also showed their genetic separation.

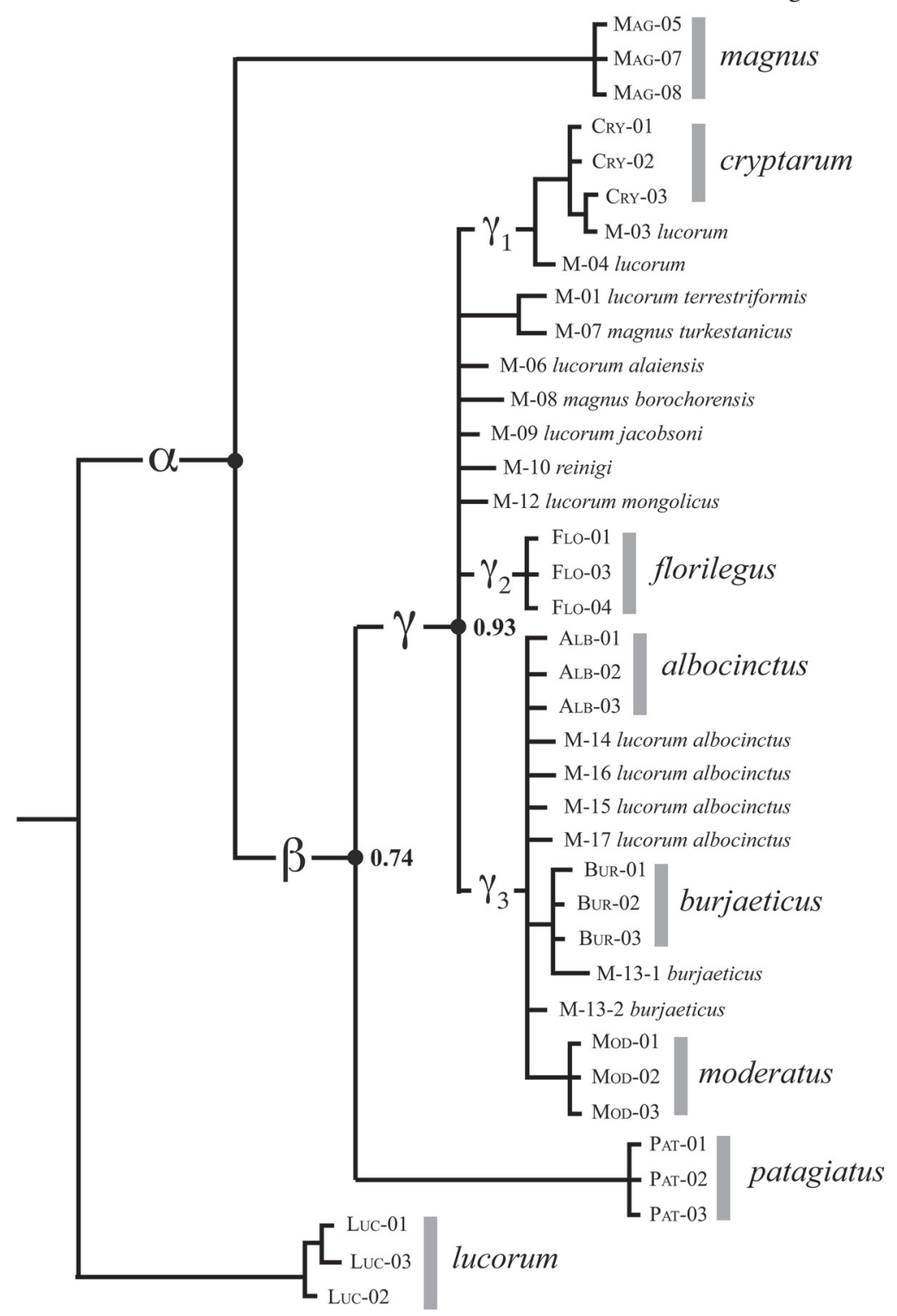

Fig. 5: Tree topology calculated as Maximum-Likelihood tree using Bayesian MCMC analysis with the general time reversal model of base substitution and gamma distribution for degraded DNA of museum specimens, only parsimony informative triplets included. 


\section{Is Bombus florilegus a separate species?}

The taxon Bombus terrestris var. japonica FrIESE, 1909, described from Yesso (= Hokkaido) and re-described as B. florilegus PAnfilov, 1956 (japonicus = name preoccupied; Dalla Torre 1890) with morphological characters of the sculpture of workers and the male genitalia, is characterised by the completely black abdomen of the females. Ito \& SAGAKami (1980) listed the morphological differences of females and males of B. florilegus compared to B. albocinctus and B. lucorum, but the variation in most of the characters remains unclear and many of them seem to overlap. Bombus florilegus is a taxon with a very restricted habitat. Figure 6 shows the distribution from Cape Nemuro at Hokkaido through the South Kuril Islands where B. florilegus is the most abundant bumblebee, with a contact zone with $B$. albocinctus of about $120 \mathrm{~km}$ on the small North Kuril Islands Shimushir, Ketoi and Rasshua (Ito \& Sagakami 1980; Ito \& Kuranashi 2000; Lelej \& Kupianskaya 2000). Compared to the wide distribution of most of the typical Bombus sensu stricto species, this restricted distribution is typical for island populations, as for instance, B. terrestris sassaricus from Sardinia or B. terrestris canariensis from the Canary Islands compared to $\mathrm{B}$. terrestris from the continent. Such isolated island populations are often genetically separated and may have their own diagnostic characters. Bombus florilegus has two unambiguous diagnostic characters that separate this taxon from $B$. albocinctus, which is comparable to the three unambiguous diagnostic characters separating B. magnus magnus of the British Isles from B. magnus flavoscutellaris of the European continent (BERTSCH 2009) or island populations of B. ignitus from Japan compared to continental populations of B. ignitus from Korea (TokоRо et al. 2010). Bombus florilegus is a taxon within the cryptarum-complex, most probably with the status of a subspecies of $B$. albocinctus. Until further evidence is available it could be treated as $B$. albocinctus florilegus Panfilov.

\section{Bombus albocinctus, a Pan-Pacific species with four taxa}

This species, described by SMITH (with type locality Kamchatka), was soon treated as the Far Eastern B. lucorum, the most obvious separating characters being the white colouration (collare, scutellum and second tergit). Davydova (2001) and Davydova \& Pesenko (2002) could not find any morphological characters to separate $B$. albocinctus and $B$. lucorum and once more established $B$. albocinctus as the Far Eastern B. lucorum, separated only by the white colouration. But the difference in colouration is not always as clear as discussed in the literature; from the 15 queen specimens from Kamchatka (ZMAS, St.Petersburg) many were not clear white (as described by Sмітн) but there was a graduation from clear white to light yellow and some were more or less citron yellow, not very different from typical $B$. lucorum. The same is true for 25 queen specimens (ZMAS, St. Petersburg) from Sakhalin, Magadan and Anadyr. Some of these specimens were clear white but some were citron yellow, at least in part, and all intermediate shades were available. But the Tamura-Nei genetic difference of the COI sequences of B. albocinctus and B. lucorum was in the order of magnitude of other Bombus sensu stricto species, therefore B. albocinctus cannot be the Far Eastern B. lucorum.

Bombus burjaeticus was described by Krüger (from type locality Kulskoje/Burjatia) mainly by characters of colouration. In the VoGT collection (ZMA, Amsterdam) there is a large number of specimens from the type locality Kulskoje (353 queens, collected 19.V.1928 by Klemm, Kulskoje, Uda Valley, Pinus forest), most in very good condition. A thorough investigation of the morphological characters still remains to be done, and it might well be that different taxa are included in this Kulskoje material, but one characteristic mentioned in Krüger's original description was quite distinctive: many specimens showed a typical greenish tint of the yellow parts of the colouration, and the dorsal part of the episternum was yellow, both characteristics typical for B. cryptarum. 
Two queens from the type series conforming to the description of Krüger were sequenced (M-13-1 and M-13-2). The 80year-old DNA was degraded but none of the 17 diagnostic characters of B. lucorum could be found (Fig. 3). Spring queens collected in June 1997 from the surroundings of Chita in Transbaikal region and tentatively designated as $B$. burjaeticus also delivered COI sequences without any diagnostic characteristics of $B$. lucorum, but close connections to $B$. cryptarum were found. These findings were confirmed by the main component of the male labial gland (unpublished results BERTSCH et al.) from artificial colonies of these cf. $B$. burjaeticus spring queens, which was ethyl dodecanoate $(\mathrm{MG}=214$, RI = 1507), not ethyl 9-octadecenoate $(\mathrm{MG}=254, \mathrm{RI}=1764)$ as found in B. lucorum (see BerTsCH et al. 2004).

In a short remark RASMONT et al. (1986:677) noted 'the resemblance of the sternite 8 of certain B. burjaeticus males with B. cryptarum' and they also noted (1986:678) that the females of $B$. albocinctus from Sakhalin

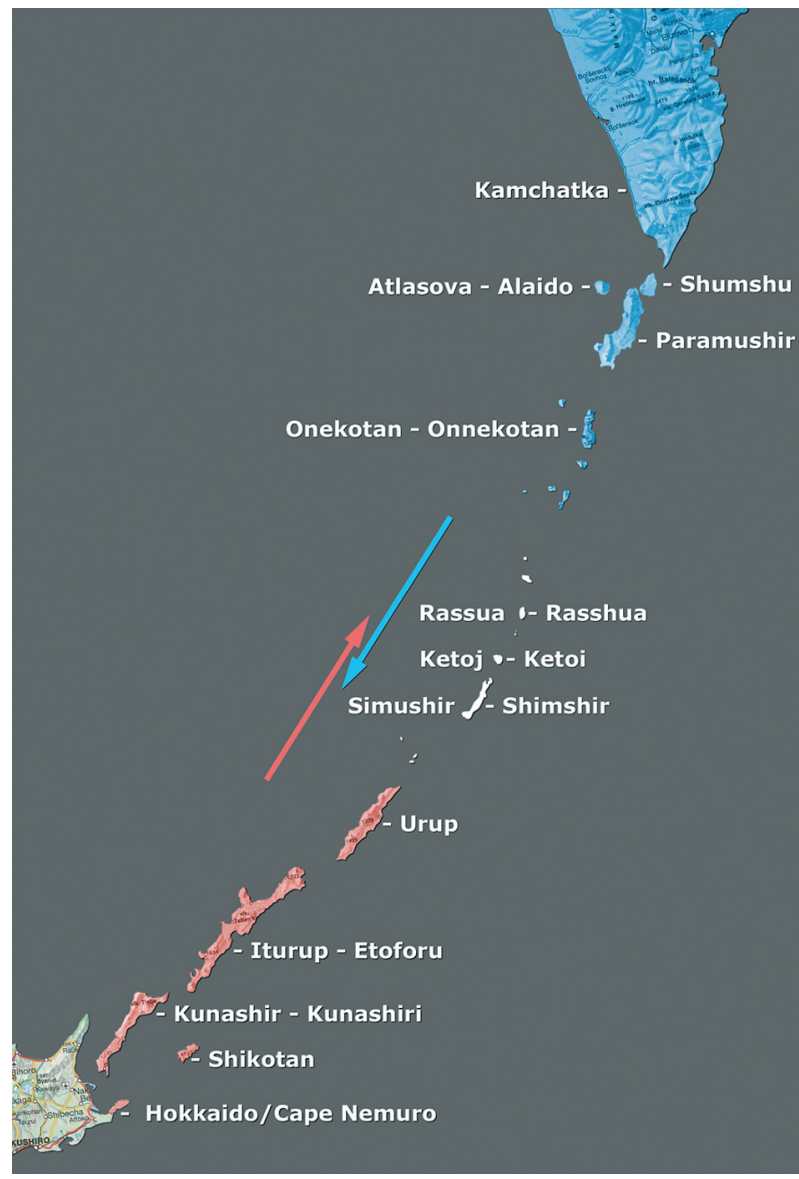

Fig. 6: Distribution of B. florilegus (red) from Cape Nemuro/ Hokkaido through the Southern Kuril Islands and of B. albocinctus (blue) from Kamchatka through the Northern Kuril Islands.

Arrows $=$ zone of contact.

are not B. lucorum but are morphologically closely conform to B. cryptarum. Specimens of B. albocinctus from Magadan, Kamchatka and the North Kuril Islands deposited in the year 2000 in GenBank by Ito \& Tanaka have been identified by morphological characters as $B$. cryptarum (M. Ito in e-mail correspondence). All of these findings and the conclusions corresponded with the results of our sequencing: B. albocinctus and B. burjaeticus belong to the same taxon, the white colouration of some Kamchatka and Far Eastern specimens is not a specific characteristic and both taxa are genetically very close to the European $B$. cryptarum. And as the North American taxon B. moderatus also belongs to B. albocinctus (BERTSCH et al. 2010), we have a taxon with a Pan-Pacific distribution. Unless possible connections between the European B. cryptarum and these Far Eastern taxa are investigated in detail, the best taxonomic conclusions are to treat $B$. burjaeticus KRÜGER as a junior synonym of $B$. albocinctus SMith and B. moderatus as B. albocinctus moderatus Cresson. 
Closing the gap: central Asiatic mountains as a bridge between Europe and the Transbaikal region

Field studies need to be undertaken to close the large gap of about $5000 \mathrm{~km}$ between the Elburtz Mountains and the Baikal area. Meanwhile, this can be attempted using the information available in the large museum collections. KRÜGER (1951) was the first to recognise that not all B. lucorumlike specimens in Asia really belonged to B. lucorum. With a trained eye and a lot of experience, as demonstrated when he separated $B$. magnus (first described in detail as B. latocinctus, KrÜGER 1939 ) and $B$. lucorum, he took the chance to fix this insight by designating these specimens extra names. Krüger knew B. cryptarum, the type specimen of his $B$. lucorum var. lehmanni from Medingen/Niedersachsen (collected 12/14.IV.1939; Vogt Collection ZMA) was a typical B. cryptarum, but he did not treat the taxon as a separate species. Instead he designated all non-lucorum specimens from Asia as B. magnus (B. magnus iranicus, B. magnus turkestanicus, $B$. magnus borochorensis, $B$. magnus mongolicus, $B$. magnus laevis, and $B$. magnus lantschouensis). As yet, $B$. magnus has not been detected in Asia, therefore, most of these names should belong to the cryptarumcomplex taxa.

After B. cryptarum was established as separate species, RASMONT et al. (1986) undertook a short survey of how different Asiatic taxa might be connected to B. cryptarum. They suggested that some of Krügers Asiatic taxa (borochorensis, turkestanicus, burjaeticus, laevis) resembled $B$. cryptarum. And there are other specimens with morphological characters which make it probable that they do not belong to B. lucorum. Good examples are B. jacobsoni Sкоrikov and B. lucorum terrestricoloratus KRÜGER; the type materials of these taxa look very much like those of $B$. cryptarum: the collare is a bit greyish instead of yellow with a clear S-band of dark hair at the border of the pronotallobus, separating the collare, and a patch of grey hair at the episternum; these specimens are typical $B$. cryptarum. All of the museum specimens suspected of belonging to $B$. cryptarum when sequenced, were proven to be distinctly different from $B$. lucorum. When only the variable triplets were used in maximum likelihood simulation they all clustered within the cryptarum-complex taxa and they shared most of the diagnostic positions of the cryptarum-complex (Fig. 3). The museum specimens from within the known distribution of B. cryptarum (M-01 to M-05) shared the diagnostic positions of B. cryptarum and the specimens from the Central Asiatic Mountains and the Himalayas shared the diagnostic positions characteristic for the Transbaikal region taxa.

A characteristic gap in the distribution of bumblebees was found in the Siberian lowlands, separating two distinct areas of distribution, one in west of the Urals and a second in the Transbaikal region and the Far East (GoRodkov 1984). Bombus cryptarum has been found far into the northern regions of Scandinavia, Finland and European Russia (Kola Peninsula), but data are lacking east of the Urals. A distribution of B. cryptarum further south in the large belt of steppe vegetation north of the Asiatic Mountains is very improbable. The sequences of the museum specimens M-01 to M-08 formed a bridge from the Elburz Mountains/Iran along the Central Asiatic Mountains Alai/Tadschikistan, Kirghizian Alatau/Kyrgyzstan, to Dzungarian Alatau/Kazakhstan, an area described from the viewpoint of the zoogeography of bumblebees by SкоRIKov (1931), where the ecological conditions may be suitable for cryptarum-complex taxa. Additional research in the Russian and Mongolian Altai and in the Sajan Mountains may close the remaining gap in the future. Then will come the time to discuss the EuropeanAsiatic-North American cryptarum-complex taxa as most probably one species, a circumpolar B. cryptarum. 


\section{Museum specimens as a valuable resource for DNA}

In the last century it was customary to name new forms according to localities (B. alaiensis, B. borochorensis, B. turkestanicus) or in honour of people (B. jacobsoni, B. reinigi). In a group where differentiation using morphological characters is as delicate as with the many taxa resembling and somehow related to $B$. lucorum, this approach leads to unsatisfactory results. According to Williams (1991:84), at least 187 names have been published concerning B. lucorum 'in the broadest sense'. Much more fieldwork is necessary but fieldwork alone will not help to clarify the situation. Collecting fresh material in the Transbaikal region and naming these specimens $B$. burajeticus because of resemblances in colouration with the type material of Krüger is not sufficient because the characters available are not conclusive. More detailed information is required and it is necessary to connect designated museum specimens with fresh material collected in the field. DNA and especially COI sequences are obvious tools which are suited to solve at least some of these problems. By carefully adjusting the amplification conditions and manually inspecting the $\mathrm{ABI}$ traces at the positions with miscoding lesions, it is possible to get reliable sequences from museum specimens, thus, connecting 80 -year-old museum specimens and fresh material is possible. However, the standard sequence length (648 bp) used for DNA bar-coding identification by COI might be a bit too short for such purposes, and we think that in the case of museum specimens, with possibly many degraded positions, it would be safer to use sequences of about double that bar-coding length (about $1200 \mathrm{bp}$ ) and to carefully compare the diagnostic positions calibrated against many sequences from fresh specimens from a broad spectrum of geographical provenances.

\section{Conclusions}

From the taxa investigated in this report, it should now be possible to use their diagnostic characters to relate unambiguously specimens to taxa, and the next step must be to find morphological characters useful for safe identification. Up until now, this task has given unsatisfactory results because the separation of the variability of characters and the delimitation of characters useful for diagnostic work has been impossible without proper designation of the specimens. The number of misidentifications in museum collections is substantial. Consequently, arguments over identification have quite often been circular and a critical re-evaluation of all the work invested into the morphological separation of taxa somehow related to B. lucorum must be done. Just the invention of a B. lucorum 'in the broadest sense' (Williams 2010) illustrates the problem, and reminds of times not so far back, when, because of difficulties of morphological separation, $B$. terrestris and $B$. lucorum from the European continent (both with white tails) were only tentatively separated as species (Hoffer 1883; Schmiedeknecht, 1930; Krüger 1920) or not at all (FAester \& FAESTER 1970; WARNKE 1981). But fortunately nobody invented a B. terrestris 'in the broadest sense'. The premature mixing of clearly separable taxa (whatever species definition is used) prohibits scientific progress and insights into biological diversity. Definable unities in nature are the objects of interest; they should be properly named to promote further investigations into their ecology and distribution. Even in museum boxes it is preferable to keep taxa separate. Divide et Impera might also be good strategy to follow in bumblebee taxonomy.

\section{Acknowledgments}

Ralf Cartar (Calgary/Canada) supplied the specimen B. moderatus (Mod-06) from Alberta/Canada and helped with discussions. Masao Ito (Sapporo) confirmed the identity of the Far Eastern GenBank sequences B. cryptarum with B. albocinctus and supplied the specimens of B. florilegus (FLO-03 and FLo-04). YURI Pesenko (Zoological Museum of the Zoological Institute of the Russian Academy of Sciences St. Petersburg, Russia) was good company during fieldwork near St. Petersburg and in the surroundings of Chita in 
Transbaikal region and supplied doublets of museum material. Jens-Peter KopelKe (Senckenberg Museum Frankfurt/M., Germany), Stefan Schmidt and Johannes Schubert (Zoologische Staatssammlungen München, Germany), and Willem Hogenes (Zoölogical Museum, Amsterdam, the Netherlands) supplied museum material. We would like to thank them all for their valuable help.

\section{References}

Ball, F. J. 1914: Les Bourdons de la Belgique. - Annales de la Societé entomologique de Belgique 58: 77-108.

Bertsch, A. 1997: Wieviele Arten der Untergattung Terrestribombus (Hymenoptera, Apidae) gibt es in Nordhessen; die Abgrenzung von B. cryptarum und B. lucorum mittels männlicher Labialdrüsensektrete und morphologischer Merkmale. - Marburger Entomologische Publikationen 2: 1-28.

Bertsch, A. 2009: Barcoding cryptic bumblebee taxa: B. lucorum, B. crytarum and B. magnus, a case study (Hymenoptera: Apidae: Bombus). - Beiträge zur Entomologie 59: 287-310.

Bertsch, A.; Schweer, H. \& Titze, A. 2004: Discrimination of the bumblebee species Bombus lucorum, B. cryptarum and B. magnus by morphological characters and male labial gland secretions (Hymenoptera: Apidae). - Beiträge zur Entomologie 54: 365-386.

Bertsch, A.; Schweer, H.; Titze, A. \& Tanaka, H. 2005: Male labial gland secretions and mitochondrial DNA markers support species status of B. cryptarum and B. magnus (Hymenoptera, Apidae). - Insectes Sociaux 52: 45-54.

Bertsch, A.; Hrabé de Angelis, M. \& Przemeck, G. K-H. 2010: A phylogenetic framework for the North American bumblebee species of the subgenus Bombus sensu stricto (Bombus affinis, B. franklini, B. moderatus, B. occidentalis \& B. terricola) based on mitochondrial DNA markers (Hymenoptera: Apidae: Bombus). - Beiträge zur Entomologie 60 (1): 229-242

Bischoff, H. 1930: Entomologische Ergebnisse der schwedischen Kamtschatka-Expedition 1920-1922. 29. Bombinae (Hymen.). - Arkiv för Zoologi 21A (no 19): 1-6.

Cha, S. Y.; Yoon, H. J.; Lee, H. E. M.; Yoon, M. H.; Hwang, J. S.; Bin, B. R.; Han, Y. S. \& Kim, I. 2007 : The complete nucleotide sequence and gene organization of the mitochondrial genome of the bumblebee, Bombus ignitus (Hymenoptera, Apidae). - Gene 392: 206-220.

Davydova, N. G. 2001. On the taxonomic status of the bumble bee Bombus albocinctus (Hymenoptera, Apidae [in Russian]. - Zoologiceskij zurnal 80: 688-692.

Davydova, N. G. \& Pesenko, Y. A. 2002: Fauna of the bees (Hymenoptera, Apoidea) of Yakutia [in Russian]. - Ent. Obozrenie (St. Petersburg) 81: 582-599.

Faester, K. \& Faester, H. K. 1970: Systematik der Mittel- und Nordeuropäischen Bombus und Psithyrus (Hym., Apidae). - Entomologiske Meddelelser 38: 257-302.

Friese, H. 1909: Neue Varietäten von Bombus (Hym.). - Deutsche Entomologische Zeitschrift 1909: 673-676.

Funk, D. J.; Wernegreen, J. J. \& Moran, N. A. 2001: Intraspecific variation in symbiont genomes: bottlenecks and the Aphid-Buchnera association. Genetics 157: 477-489.

Gorodkov, K. B. 1984: Range types of insects of tundra and forest zones of European Part of U.S.S.R [in Russian]. - In: Arealy nasekomikj europeskoy chasti SSSR. ed. K. B.Gorodkov.

HiLlis, D. M. 1994: Homology in molecular biology. - In: Homology the hierarchical basis of comparative biology. Edited by B. H. Hall. Academic Press, London New York: pp. 197-227.

Hoffer, E. 1883: Die Hummeln Steiermarks. Lebensgeschichte und Beschreibung derselben. II. Hälfte. -98 pp., Graz.

Huelsenbeck, J. P. \& Ronquist, F. 2001: MrBayes: Bayesian inference of phylogeny. - Bioinformatics 17: 754-755.

Ito, M. \& Sagakami S. F. 1980: The bumblebee fauna of the Kurile Islands (Hymenoptera: Apidae). - Low. Temp. Sci., Serie B 38: 23-51. 
Ito, M. \& Kuranishi R. B. 2000: Bumble bees (Hymenoptera. Apidae) ocurring in the Kamtschatka Peninsula and the North Kuril Islands. - Nat. Hist. Res. (Special Issue no. 7): 281-289.

KRÜGER, E. 1920: Beiträge zur Systematik und Morphologie der mitteleuropäischen Hummeln. - Zoologische Jahrbücher Abt. Systematik 42: 289-464.

KRÜGER, E. 1939: Die Hummeln und Schmarotzerhummeln von Sylt und dem benachbarten Festland. - Schriften Naturw. Ver. Schleswig-Holstein 23: 28-123.

KrÜGer, E. 1951: Phänoanalytische Studien an einigen Arten der Untergattung Terrestribombus O. Vogt (Hymenoptera, Bombidae). I. Teil. - Tijdschrift voor Entomologie 93: 141-197.

Kumar, S.; Nei, M.; Dudley, J. \& Tamura, K. 2008: MEGA. A biologist-centric software for evolutionary analysis of DNA and protein sequences. Briefings in Bioinformatics 9: 299-306.

Lelej, A. S. \& Kupianskaya, A. N. 2000: The bumble-bees (Hymenoptera, Apidae, Bombinae) of the Kuril Islands. - Far Eastern Entomologist 95: 1-17.

Maddison, W. P. \& Maddison, D. R. 2002: MacClade Analysis of Phylogeny and Character Evolution. Sunderland, Sinauer Associates: 398 pp.

NyLANDeR, W. 1848: Adnotationes in expositionem monographicam apum borealium. - Meddelanden af Societas pro Fauna et Flora Fennica Förhandlingar 1: 164-282.

Panfilov, D. V. 1956: Materialy po sistematike shmeley (Hymenoptera, Bombinae). - Zoologiceskij zurnal 35: 1325-1334.

Pedersen, B. V. 2002: European bumblebees (Hymenoptera: Bombini) - phylogenetic relationships inferred from DNA sequences. - Insect Systematics \& Evolution 33: 361-386.

Posada, D. 2008: jModelTest: phylogenetic model averaging. - Molecular Biology and Evolution 25: 1253-1256.

Rasmont, P. 1981: Redéscription d'une éspece meconnue de Bourdon d'europe Bombus lucocryptarum BaLl. 1914 n. status (Hymenoptera, Apidae, Bombinae). - Bulletin et Annales de la Société Royale entomologique de Belgique 117: 149-154.

Rasmont, P. 1983: Les Bourdons du genre Bombus Latreille sensu stricto en Europe Occidentale et Centrale (Hymenoptera, Apidae). - Spixiana 7: 135-160.

Rasmont, P.; Scholl, A.; De Jonghe, R.; Obrecht, E. \& Adamski, A. 1986: Identité et variabilité des mâles de bourdons du genre Bombus LATreille sensu stricto en Europe occidentale et centrale (Hymenoptera; Apidae, Bombinae). - Revue Suisse Zoologique 93: 661-682.

Schmiedeknecht, O. 1930: Die Hymenopteren Nord- und Mitteleuropas mit Einschluß von England, Südschweiz, Südtirol und Ungarn: Jena, Gustav Fischer.

Scholl, A.; Oвrecht, E. \& Owen, R. E. 1990: The genetic relationship between Bombus moderatus Cresson and the Bombus lucorum auct species complex (Hymenoptera:Apidae). - Canadian Journal of Zoology 68: 2264-2268.

Skorikov, A. 1913: Neue Hummelformen (Hymenoptera, Bombidae) V. - Russkoe éntomologicheskoe Obozrênie 13: 171-175.

SкоRıкоv, A. 1931: Die Hummelfauna Turkestans und ihre Beziehungen zur zentralasiatischen Fauna (Hymenoptera, Bombidae). - In: Pamir Expedition 1928. Abhandlungen der Expedition, Lieferung VIII. Zoologie. Ed. V. A. Linholm. Leningrad, Academy of Sciences: pp. 175-247.

TAMUra. K. \& NeI, M. 1993: Estimation of the number of nucleotide substitutions in the control region of mitochondrial DNA in humans and chimpanzees. - Molecular Biology and Evolution 10: 512-526.

Tamura, K.; Dudley, L.; Nei, M. \& Kumar, S. 2007: Mega 4.0: Molecular Evolutionary Genetics Analysis (Mega) software version 4.0. - Molecular Biolology and Evolution 24: 1596-1599.

Tkalcu, B. 1967: Sur deux espèces de Bourdons décrites par William Nylander. - Bulletin de la Société Entomologique de Mulhouse 1967: 41-58.

Tkalcu, B. 1974: Eine Hummelausbeute aus dem Nepal-Himalaya (Insecta, Hymenoptera, Apoidea, Bombinae). - Senckenbergiana biologica 55: 311-349. 
Tokoro, S.; Yoneda, M.; Kunitake, Y. K. \& Goka, K. 2010: Geographic variation in mitochondrial DNA of Bombus ignitus. - Applied entomology and zoology 45: 77-87.

Vogt, O. 1911: Studien über das Artproblem. 2. Mitteilung. Über das Variieren der Hummeln 2. Teil (Schluß). - Sitzungsberichte der Gesellschaft Naturforschender Freunde zu Berlin Jahrgang 1911: 31-74.

Warncke, K. 1981: Die Bienen des Klagenfurter Beckens. - Carinthia II, 91. Jahrgang 1981: 275-348.

Williams, P. 1991: The bumble bees of the Kashmir Himalaya (Hymenoptera: Apidae, Bombini). - Bulletin of the British Museum Natural History (Entomology) 60: 1-204.

Williams, P. H. 2010: www.nhm.ac.uk/research-curation/projects/bombus/bo.html\#lucorum

\section{Authors' addresses:}

Prof. Dr. Andreas Bertsch

Department of Biology, Philipps-University Marburg

Karl-von-Frisch Straße 8

35032 Marburg, Germany

e-mail: bertsch@staff.uni-marburg.de

Prof. Dr. Martin Hrabé de Angelis and Dr. Gerhard K. H. Przemeck

Institute of Experimental Genetics, Helmholtz-Zentrum München

Ingoldstädter Landstraße 1

85764 Neuherberg, Germany

e-mail: hrabe@helmholtz-muenchen.de and przemeck@helmholtz-muenchen.de

\section{Subject editor:}

Prof. Dr. H. H. DATHE 